\title{
PERANCANGAN SISTEM INFORMASI REKAM JEJAK DOSEN BERBASIS WEB PADA UNIVERSITAS DHYANA PURA
}

\author{
Christian Tonyjanto ${ }^{1)}$ Devi Marlita Martana ${ }^{2)}$ \\ Program Studi Sistem Informasi ${ }^{1)}$ \\ Program Studi Perekam dan Informasi Kesehatan ${ }^{2)}$ \\ Fakultas Ilmu Kesehatan Sains Dan Teknologi ${ }^{12)}$ \\ Universitas Dhyana Pura ${ }^{1) 2}$. \\ christiantonyjanto@undhirabali.ac.id ${ }^{l)}$ devimarlita@undhirabali.ac.id ${ }^{2)}$
}

\begin{abstract}
This study purpose is to produce Web-based applications that serve as a tool of conducting the process of submission of functional positions or lecturer academic positions conducted every 2 years. Currently conducted by the University, and in particular the Study Program is still doing the file form lecturers who have been submitted in the last 2 years or 2 years to come physically or hardcopy. This is not very much in line with the university's goal of doing GO-Green Campus. With this application, it is expected that the University can apply GOGreen Campus, have the track record of lecturer and assist the lecturer's task in calculating the credit score already obtained at the time will increase the credit score.
\end{abstract}

Keyword : Information Systems, Track Record, and Web.

\begin{abstract}
ABSTRAK
Penelitian ini bertujuan untuk menghasilkan Aplikasi berbasis web yang berfungsi sebagai alat bantu dari melakukan proses pengajuan jabatan fungsional atau jabatan akademik dosen yang dilakukan setiap 2 tahun. Saat ini yang dilakukan oleh Universitas, dan secara khususnya Program Studi masih melakukan penyimpanan file borang dosen yang telah diajukan pada 2 tahun yang lalu atau 2 tahun yang akan datang secara fisik atau hardcopy. Hal ini sangat tidak sejalan dengan tujuan universitas untuk melakukan GO-Green Kampus. Dengan adanya Aplikasi ini, diharapkan Universitas bisa menerapkan GO-Green Kampus, memiliki data rekam jejak dosen dan membantu tugas dosen dalam menghitung angka kredit yang sudah didapatkan pada saat akan melakukan kenaikan angka kredit.

Kata kunci: Sistem Informasi, Rekam Jejak(Track Record), Dosen, dan Web
\end{abstract}




\section{PENDAHULUAN}

Sistem Informasi adalah kombi-nasi dari manusia, fasilitas atau alat teknologi, media, prosedur dan pengen-dalian yang ditujukan untuk mengatur jaringan ko-munikasi yang penting, proses transaksi tertentu dan rutin, membantu manajemen dan pemakai intern dan ekstern dan menyediakan dasar untuk mengambil keputusan yang tepat (dalam John F. Nash, 1995: 8).

Sistem Informasi pada Undhira, selain hanya merekam seluruh data - data penting dosen seperti data dasar atau awal dosen tetapi juga memiliki seluruh data yang terkait dengan dosen tersebut seperti proses tri dharma perguruan tinggi dan pengajaran yang harus dijalankan oleh dosen yang bersangkutan. Pada sistem informasi ini juga diberikan kemudahan untuk universitas dimana bila dosen memang harus melakukan naik jabatan akademik sudah bisa diketahui dan hanya tinggal melakukan komunikasi dengan dosen yang bersangkutan untuk diajukan naik jabatan akademik.

Pada Sistem Informasi berbasis web pada Undhira, bertujuan untuk me-mudahkan dan data lebih terpusat untuk dapat diakses dimana saja tanpa harus melakukan pemasangan atau penyesuaian pada setiap perangkat keras yang dimiliki dosen. Serta juga untuk memudah akses sistem informasi ini tanpa ada batasan tempat dan waktu yang diperlukan dan data dapat dilihat oleh bagian sumber daya manusia untuk melakukan monitoring data yang dimasukan ke sistem. Bila ada data yang kurang bisa langsung dikomunikasi oleh Personalia ke dosen yang bersangkutan. Dengan adanya sistem ini bisa memfasilitasi 13 program studi dengan jumlah dosen sebanyak 201 orang, dan masih terus bertambah seiring dengan meningkatnya dan rasio dosen dengan jumlah mahasiswa. Untuk menghindari data dosen yang terus meningkat setiap akhir semester, dimana diperlukan pencatatan atau perekaman secara fisik agar pada saat dosen yang bersangkutan harus melakukan penghitungan angka kredit yang dilakukan setiap 2 tahun bagi yang sudah memiliki jabatan akademik dosen dan bagi yang belum memiliki sudah dapat terekam dan hanya perlu dilakukan pencetakan saja sesuai dengan kebutuhan dan linier dari kegiatan proses pengajaran.

Dengan sistem informasi berbasis web yang dirancang ini, sebenarnya sudah dapat dilakukan dengan mudah untuk Undhira. Namun belum ada yang me-nyesuaikan dengan kebutuhan pengguna ke dalam sistem yang akan dipergunakan. Serta berfungsi untuk memudahkan seluruh dosen pada lingkungan Undhira dalam menyimpan dokumen yang diperlukan serta Personalia dan LP2M dapat memiliki database dosen yang akurat.

\section{MODEL, ANALISIS, DESAIN DAN IMPLEMENTASI}

\section{Sistem Informasi}

Computer Based Information System (CBIS) atau yang dalam Bahasa Indonesia disebut juga Sistem Informasi Berbasis Komputer merupakan sistem pengolah data menjadi sebuah informasi yang berkualitas dan dipergunakan untuk suatu alat bantu pengambilan keputusan. Sistem Informasi yang akurat dan efektif, dalam kenyataannya selalu ber-hubungan dengan istilah "computer-based" atau pengolahan informasi yang berbasis pada komputer. Sistem Informasi "berbasis komputer" mengandung arti bahwa komputer me-mainkan peranan penting dalam sebuah sistem informasi.

Secara teori, penerapan sebuah Sistem Informasi memang tidak harus menggunakan komputer dalam kegiatannya. Tetapi pada prakteknya tidak mungkin sistem informasi yang sangat kompleks itu dapat berjalan dengan baik jika tanpa adanya komputer. Sistem Informasi me-rupakan sistem pembangkit informasi. Dengan integrasi yang dimiliki antar subsistemnya, sistem informasi akan mampu menyediakan informasi yang berkualitas, tepat, cepat dan akurat sesuai dengan manajemen yang membutuhkannya. (http://repository.usu.ac.id/bitstream/12345678 9/16955/4/Chapter\%20II.pdf)

\section{Data}

Menurut berbagai kamus bahasa InggrisIndonesia, data di-terjemahkan sebagai istilah yang berasal dari kata "datum" yang berarti fakta atau bahan-bahan keterangan. Data merupakan deskripsi dari sesuatu dan kejadian yang kita hadapi. Data adalah fakta yang jelas lingkup, tempat, dan waktunya. Data diperoleh dari sumber data primer atau sekunder dalam bentuk berita tertulis atau sinyal elektronis. Jadi pada intinya, data merupakan kenyataan yang meng-gambarkan suatu kejadian dan merupakan kesatuan nyata yang nantinya akan digunakan sebagai bahan dasar suatu informasi.

(dalamhttp://repository.usu.ac.id/bitstream/123 456789/16955/4/Chapter\%20II.pdf). 


\section{Rekam Jejak}

\section{Kinerja}

Secara umum istilah kinerja digunakan untuk menyebut prestasi atau tingkat keberhasilan individu maupun kelompok individu. Kinerja adalah gambaran mengenai tingkat pencapaian pelaksanaan suatu kegiatan atau program atau kebijakan dalam mewujudkan sasaran, tujuan, misi, dan visi organisasi yang tertuang dalam strategic planning suatu organisasi. Kinerja bisa diketahui hanya jika individu atau kelompok individu tersebut mempunyai kriteria ke-berhasilan yang telah ditetapkan. Kriteria keberhasilan ini berupa tujuan-tujuan atau target-target tertentu yang hendak dicapai. Tanpa ada tujuan atau target, kinerja seseorang atau organisasi tidak mungkin dapat diketahui karena tidak ada tolak ukurnya (Mohamad Mahsun, 2006: 25).

Pengukuran kinerja adalah proses penilaian kemajuan pekerjaan terhadap tujuan dan sasaran yang telah ditentukan sebelumnya, termasuk informasi atas: efisiensi penggunaan sumber daya dalam menghasilkan barang dan jasa; kualitas barang dan jasa (seberapa baik barang dan jasa diserahkan kepada pelanggan dan sampai seberapa jauh pelanggan terpuaskan); hasil kegiatan di-bandingkan dengan maksud yang diinginkan, dan efektivitas tindakan dalam mencapai tujuan (Robertson, 2002 dalam Mohamad Mahsun, 2006: 25) "feedback from the accountant to management that provides information about how well the actions represent the plans; it also identifies where managers may need to make corrections or adjustment in future planning and controlling activities" Dari definisi-definisi tersebut dapat disimpulkan bahwa pengukuran kinerja adalah tindakan pengukuran yang dilakukan terhadap berbagai aktivitas dalam rantai nilai yang ada pada organisasi (Sony Yuwono dkk, 2004:23). Pengukuran kinerja me-rupakan salah satu faktor yang amat penting bagi suatu organisasi, pe-ngukuran kinerja menurut Lynch dan Cross (1993) dalam Sony Yuwono dkk (2006:29) bermanfaat untuk:

Menelusuri kinerja terhadap harapan pelanggan sehingga akan membawa perusahaan lebih dekat pada pelanggannya dan membuat seluruh orang dalam organisai terlibat dalam upaya memberi kepuasan kepada pelanggan.

- Memotivasi pegawai untuk me-lakukan pelayanan sebagai bagian dari mata rantai pelanggan dan pemasok internal.

- Mengidentifikasi berbagai pem-borosan sekaligus mendorong upaya-upaya pengurangan terhadap pemborosan tersebut.

- Membuat suatu tujuan strategis yang biasanya masih kabur menjadi lebihkonkret sehingga mem-percepat proses pembelajaran organisasi.

- Membangun konsensus untuk melakukan suatu perubahan dengan memberi "reward" atas perilaku yang diharapkan tersebut.

Dari beberapa pengertian dan penjabaran tentang pentingnya pe-ngukuran kinerja yang telah di-kemukakan, dapat disimpulkan bahwa pengukuran kinerja dapat dijadikan sebagai ukuran keberhasilan suatu organisasi dalam kurun waktu tertentu dan hasil pengukuran kinerja dapat dijadikan sebagai masukan untuk per-baikan dan peningkatan organisasi di masa yang akan datang.

\section{Alat pengukuran Kinerja non Keuangan}

Pentingnya pengukuran kinerja non keuangan disebabkan karena organisasi menghadapi perubahan lingkungan secara cepat. Untuk dapat bersaing, organisasi membutuhkan sistem informasi yang berkemampuan menangkap informasi secara cepat dan efektif. Meskipun analisis catatan keuangan adalah penting, tetapi perhitungan tersebut kurang menyediakan informasi yang akurat mengenai kemampuan organisasi. Informasi yang diukur dalam satuan keuangan merupakan hasil dari keputusan masa lalu.

Dalam menghadapi perubahan lingkungan dan persaingan yang semakin meningkat, pengukuran non keuangan menjadi penting untuk dilakukan karena banyak data-data non keuangan yang bersifat kualitatif yang menyangkut operasional perusahaan maupun yang menyangkut hubungan organisasi dengan lingkungan eksternalnya yang mempunyai pengaruh besar terhadap kelangsungan hidup perusahaan. Dengan kata lain, pengukuran non keuangan merupakan pengukuran atas aktiva tak berwujud dan kapabilitas organisasi yang dapat membantu organisasi untuk mencapai keberhasilan. Aktiva tak berwujud tidak dapat diukur dalam pengukuran keuangan karena tidak dicantumkan dalam laporan keuangan suatu organisasi. Hal ini terjadi karena sulit untuk menghitung nilai finansial aktiva tak berwujud tersebut. Padahal aktiva tak berwujud tersebut mempengaruhi laporan keuangan suatu organisasi dalam penggunaannya.

Ukuran-ukuran non keuangan tidak dapat menggantikan ukuran-ukuran keuangan, keduanya saling melengkapi (Kaplan \& 
Norton, 2000). Pengukuran kinerja berdasarkan non keuangan akan berhubungan secara langsung dengan strategi bisnis dan dapat berubah sesuai dengan perubahan kondisi lingkungan bisnis. Ukuran-ukuran non keuangan yang bisa digunakan oleh perusahaan antara lain kepuasan pelanggan, loyalitas pelanggan, kemampuan karyawan, proses internal yang responsif dan dapat diprediksi, dan sebagainya. Ukuran-ukuran non keuangan tersebut merupakan aktiva intelektual dan tak berwujud yang dimiliki oleh suatu perusahaan.

\section{Dosen}

Menurut Prof Dede, semua mahasiswa yang memutuskan untuk ambil studi di perguruan tinggi, pasti memiliki angan-angan besar dalam dirinya untuk menjadi seseorang yang berbeda dengan mereka yang putus sekolah pada jenjang menengah atau jenjang pendidikan dasar. Sebahagian dari para mahasiswa mungkin ada yang memiliki idealisme untuk menjadi ilmuwan, dan terus menempuh studi pada jenjang strata satu, dua dan tiga, sehingga menjadi seorang ilmwan bergelar akademik Doktor, atau paling tidak bergelar akademik Master. Akan tetapi, pada umumnya mereka berangan-angan untuk menjadi profesional dan dapat mengakses kesempatan kerja sebagai profesional, diterima kerja sebagai profesional, dan memperoleh penghasilan yang layak sebagai seorang profesional. Untuk itu, mereka harus terlahir sebagai sarjana yangcerdas dan berdaya saing. Angan-angan tersebut, dimiliki oleh hampir semua mahasiswa. Oleh sebab itu, ketika membaca brosur dan informasi program studi, mereka akan men-cermati profile dari program studi tersebut serta nama-nama dosen pengampu mata kuliah pada program studi yang mereka minati itu. Program studi paling besar jumlah Guru Besar, atau Doktornya, dan memiliki captive market yang bagus, pasti akan mem-peroleh peminat paling besar dari seluruh calon mahasiswa. Jika tidak terpenuhi ketiga-tiganya, maka akan secara gradual turun pada dua kriteria, sampai hanya pada satu kriteria saja.

Penilaian para pengguna baik sebagai pemakai lulusan maupun sebagai pelanggan jasa layanan pendidikan, merupakan masukan yang amat berharga bagi universitas untuk terus meningkatkan kualitas layanan, agar senantiasa terus meningkatkan kualitas proses pendidikan untuk menghasilkan lulusan cerdas berdaya saing. Ukuran cerdas berdaya saing bagi lulusan sarjana strata satu adalah penyerapan pasar kerja. Semakin cepat seorang sarjana terserap pasar tenaga kerja, maka semakin berkualitas kesarjanaan nya, dan semakin berkualitas pula institusi yang me-lahirkannya. Setidaknya ada tiga jalur penyerapan, pertama, wira usaha, yakni kemampuan entrepreneurship dari seorang sarjana untuk me-ngembangkan wira usaha mandiri, dalam sektor apa saja kegiatan bisnis mereka, patut dihargai, dan ini adalah lulusan yang paling berkualitas. Kemudian kedua, masuk pasar kerja yang linier dengan bidang ilmunya, contoh alumni Tarbiyah yang menjadi guru, alumni syari'ah yang menjadi hakim agama, atau pengacara untuk kasus-kasus yang menjadi kewenangan Peradilan Agama, alumni fakultas da'wah yang menjadi da'i, alumni perbankan syari'ah yang menjadi pegawai bank syari'ah. Kemudian ketiga, masuk pasar kerja yang tidak sesuai dengan keahlian keilmuannya, tapi menjadi orang sukses dalam bidang dimasukinya itu, seperti alumni Akidah Falsafat yang menjadi politisi di DPR, atau DPRD. Alumni tafsir yang menjadi Bupati atau Gubernur. Alumni tarbiyah yang menjadi penguasa. Dan UIN, IAIN serta STAIN adalah lembaga pendidikan yang sukses mengantarkan para alumninya untuk menjadi orang sukses di luar keahliannya itu.

Kunci sukses mereka adalah dosen yang memiliki tiga kualifikasi utama, yakni memiliki kapabilitas, loyalitas ${ }^{[1]}$ dan akuntabilitas. Seorang dosen harus memilikikapabilitas yang baik dalam bidang keilmuannya, dan itu ditandai dengan pendidikan yang linier dengan cabang atau bidang ilmu yang akan menjadi tanggungjawabnya, kemudian, produktif dalam menulis paper dalam bidang ilmunya itu, baik untuk bahan ajar maupun paper untuk disampaikan dalam forum seminar atau simposium, dan bahkan pada jenjang kepangkatan untuk memperoleh Guru Besar, seorang dosen harus menulis sebuah buku akademik yang tidak terikat dengan silabus perkuliahan. Kemudian dosen harus memiliki loyalitas yang baik, karena dosen yang pintar tidak akan bisa menghantarkan para mahasiswanya menjadi pintar, jika dia tidak pernah masuk kelas, atau masuk kelas hanya dua kali di awal dan di akhir semester, sementara 12 kali pertemuan lainnya, para mahasiswa hanya didampingi para asisten yang baru lulus master, maka para mahasiswa akan menjadi sarjana yang premature, karena dibina dan dididik bukan oleh Guru Besarnya, atau pengamu utama mata kuliah tersebut. Atau dosen itu masuk 14 kali dalm satu semester, tapi para mahasiswa tidak dibimbing untuk 
pengembangan keilmuannya dengan tugastugas mandiri yang seharusnya diberikan mingguan, maka mahasiswa akan menjadi sarjana yang akan kalah bersaing di pasar tenaga kerja oleh sarjana lain dari universitas lain. Kemudian dosen juga harus akuntabel, yakni masuk 14 kali persemester, dan di kelas mereka mengajar atau mendampingi para mahasiswanya belajar, bukan menggunjingi presiden, menteri, para anggota DPR atau bahkan menggunjingi pimpinan fakultas dan universitas. Para mahasiswa masuk kelas siap untuk belajar, bukan siap untuk diajak berfikir negatif tentang orang lain yang akan sangat kontraroduktif untuk menghantarkan mereka menjadi sarjana yang cerdas berdaya saing.

Kunci sukses perkuliahan yang dapat menghantarkan para mahasiswa menjadi sarjana yang cerdas berdaya saing adalah dosen, karena kendati universitas didukung dengan per-pustakaan yang baik, jika tidak digerakkan oleh dosen, para mahasiswa tidak akan dengan optimal memanfaatkan perpustakaan sebagai sumber belajar mereka. Demikian pula dengan laboratorium, jika dosen tidak mendisain perkuliahan yang memanfaatkan laboratorium sebagai sarana pembelajaran, maka keberadaan laboratorium tidak akan membawa manfaat untuk menghantarkan para mahasiswa menjadi sarjana yang cerdas berdaya saing. Begitu pentingnya posisi dosen, Indonesia secara serius meregulasi pelaksanaan tugas dosen, serta jaminan hidup yang disiapkan negara untuk profesi mulia tersebut, melalui UU No. 14 tahun 2005 tentang Guru dan Dosen. Dalam Undang-undang tersebut ditegaskan bahwa dosen adalah pendidik profesional dan ilmuwan dengan tugas utama mentransformasikan, me-ngembangkan, dan menyebarluaskan ilmu pengetahuan, tek:nologi, dan seni melalui pendidikan, penelitian, dan pengabdian kepada masyarakat ${ }^{[2]}$. Dosen adalah pendidikan profesional dan ilmuwan, yakni seseorang yang memiliki kapabilitas dalam bidang keilmuan tertentu, dan dengan kapabilitasnya itu, dia bisa mengajar, meneliti untuk mengembangkan teori-teori serta teknologi dalam bidang keilmuannya, dan bahkan melakukan pengabdian pada masyarakat untuk memvalidasi teori atau teknologi yang sudah dihasilkan lewat penelitiannya. Kedudukan dosen, sebagaimana diatur pada pasal $5 \mathrm{UU}$ No. 14 tahun 2005 tentang Guru dan Dosen, ditegaskan bahwa kedudukan dosen sebagai tenaga profesional menjadi agen pembelajaran, pengembang ilmu pengetahuan, teknologi, dan seni, serta pengabdi kepada masyarakat berfungsi untuk meningkatkan mutu pendidikan nasional ${ }^{[3]}$.

\section{Metodologi Penelitian}

Penelitian yang dilakukan melalui beberapa tahapan yang harus dilakukan agar sistem informasi yang dibuat bisa memberikan fasilitas yang mudah bagi program studi dan perguruan tinggi, agar bisa sejalan dengan rencana yang diharapkan. Adapun prosesnya sebagai berikut;

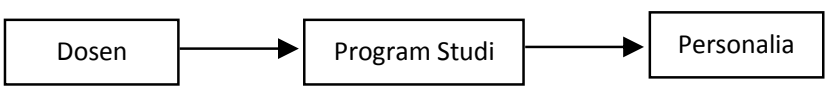

Gambar 1 Alur Proses Pengajuan

Dengan penjelasan dari proses sebagai berikut;

\section{Dosen}

Pada Dosen, sebagai penyedia data untuk melengkapi dan mem-persiapkan beberapa data penting seperti identitas dan kelengkapan lainnya yang

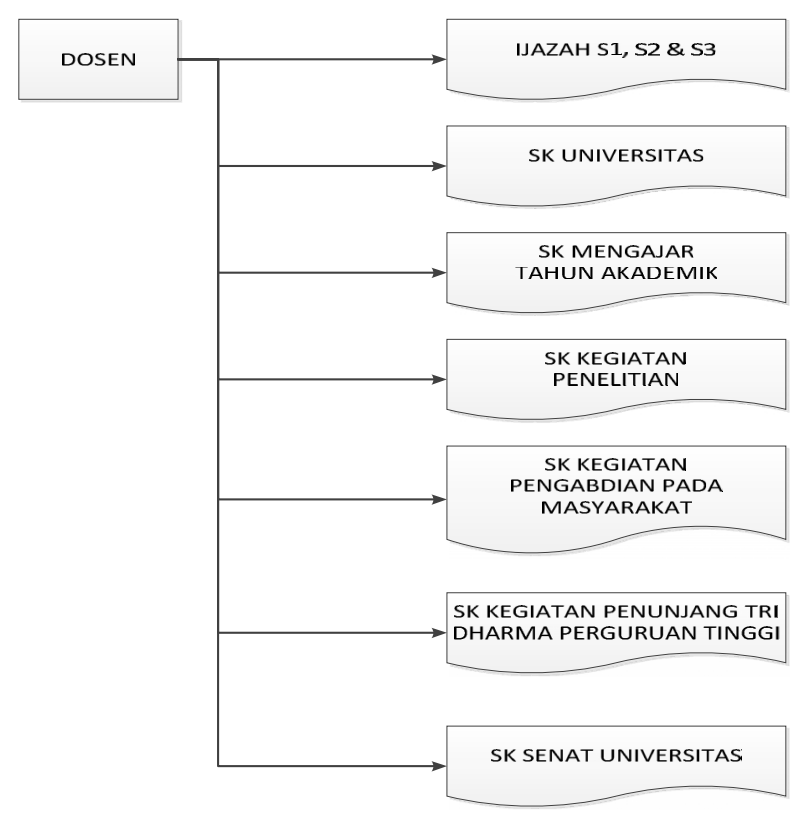

Gambar 2 Kelengkapan Dokumen Dosen 


\section{Universitas}

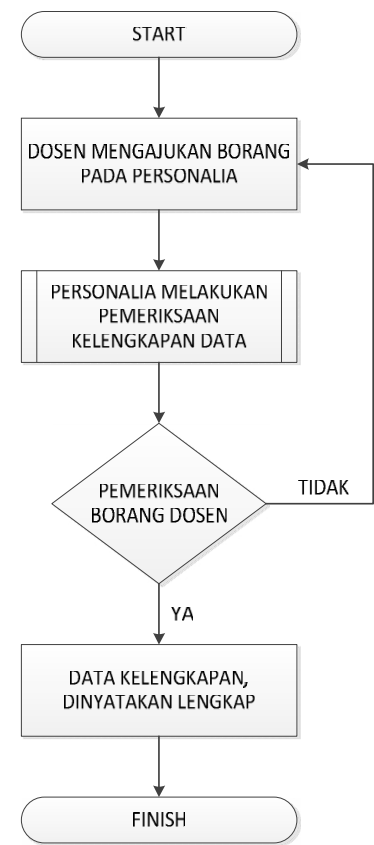

Gambar 3. Proses Pemeriksaan Kelengkapan oleh Universitas

\section{Kopertis}

Pada Kopertis, berfungsi sebagai tempat atau lembaga dimana seorang Dosen melakukan pengajuan Jabatan Fungsional atau Jabatan Akademik.

\section{Analisis dan Perancangan Sistem}

Melihat dari hasil analisa pada gambar 3 dapat dilakukan identifikasi untuk kebutuhan dari perancangan sistem informasi rekam jejak dosen berbasis web dan juga membandingkan dengan sistem informasi yang sudah ada pada lingkungan undhira, dapat diberikan beberapa identifikasi sebagai berikut;

a. Menyiapkan rancangan sistem rekam jejak terperinci

b. Mengidentifikasi berbagai altenatif input data yang diperlukan

c. Mengevaluasi berbagai data yang akan diinput kedalam sistem

d. Memilih konfigurasi terbaik

e. Menyiapkan usulan penerapan

Dari penjelasan diatas, dapat disimpulkan bahwa perancangan sistem merupakan proses pen-terjemahan kebutuhan pemakai informasi ke dalam suatu rancangan untuk memenuhi kebutuhan pemakai dan memberi gambaran yang lebih jelas untuk dijadikan pertimbangan dalam perancangan sistem informasi.

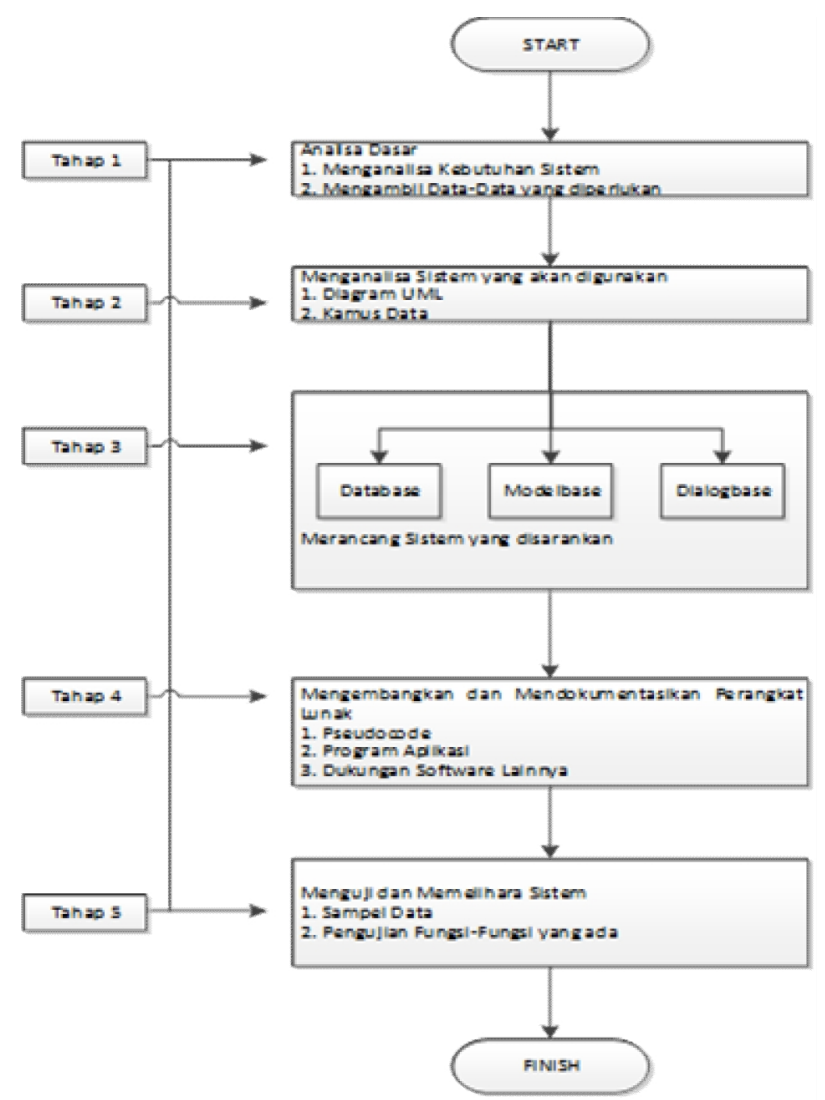

Gambar 4 Tahapan Perancangan Sistem Informasi Rekam Jejak Dosen 


\section{Hasil dan Pembahasan}

Dari hasil penelitian yang dilakukan dengan menggunakan konsep sistem informasi. Adapun proses perancangan sistem yang dilakukan adalah sebagai berikut;

Model Basisdata yang dirancang dalam sistem menggunakan model data logika atau konseptual dan model data fisik. Sebelum membangun model data tersebut terlebih dahulu ditentukan objek yang terdapat dalam sistem. Adapun hasil dari identifikasi sebelumnya melalui kamus data. Obyek-obyek tersebut antara lain;

- Identitas

- Status Kepegawaian

- Riwayat Kependidikan

- Kegiatan

- Jabatan Akademik

Dengan dilakukan penentuan obyek-obyek tersebut selanjutnya dilakukan organisir dan identifikasi hubungan antar obyek. Menurut kurata(1996), terdapat 3 jenis dasar hubungan antar objek, yaitu :
- Subkelas

Merupakan hubungan antara kelas objek dengan kelas objek diatasnya, dimana objek-objek ini memiliki properti dan perilaku kelas diatasnya. Hubungan ini diidentifikasi dengan menggunakan klausa "adalah(is a)".

- Container (wadah)

Merupakan hubungan yang terjadi karena suatu objek terbentuk dari objek lain. Hubungan diidentifikasi dengan menggunakan bahasa klausa "memiliki (has a)"

- Kolaborator Merupakan hubungan yang terjadi apabila objek perlu menggunakan objek lain untuk tujuan tertentu. Hubungan ini diidentifikasi dengan menggunakan klausa "memakai (use)"

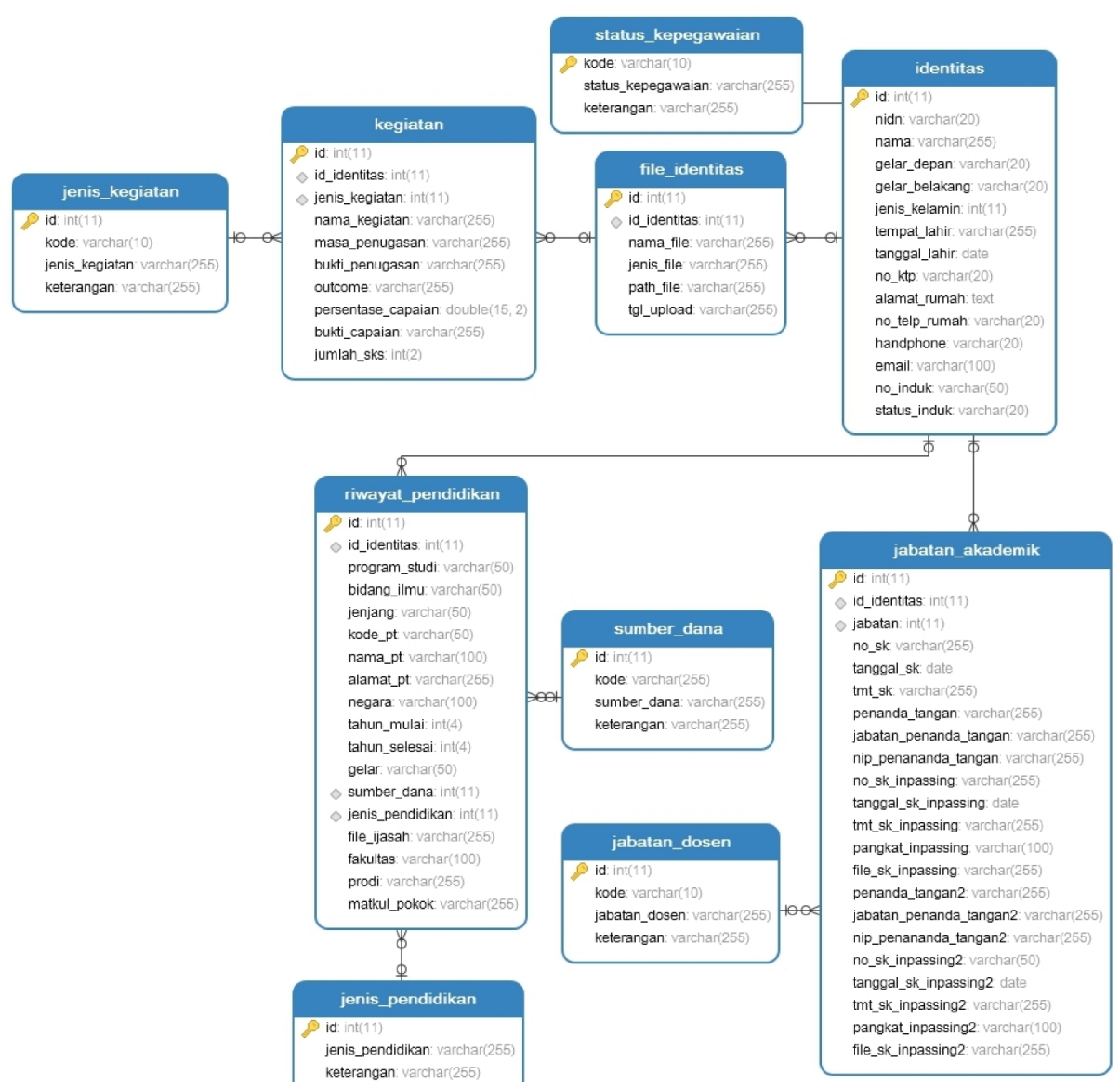

Gambar 5. Model Data Konseptual Sistem Rekam Jejak Dosen Dosen 
Hubungan yang terjadi antara objek pada perancangan sistem informasi ini adalah hubungan container dan kolaborator. Untuk menggambarkan hubungan antar objek tersebut, selanjutnya dibangun model logika dari basisdata. Model data logika atau model data konseptual menggambarkan struktur logis dari basisdata, serta kardinalitas antar objek. Adapun model data konseptual dari basis data Sistem Rekam Jejak Dosen berbasis web seperti pada gambar 4.x menunjukkan atribut dari masing-masing obyek, hubungan obyek, primary identifier yang secara unik mengidentifikasi obyek serta mandatory yang menyatakan atribut harus berisi data (tidak boleh kosong).

\section{Perancangan Tampilan}

Pada sub bagian ini, dapat ditampilkan rancangan tampilan pengguna dari sistem rekam jejak dosen. Pada tampilan sistem ini menggunakan tema gratis dari bootstrap yang bisa unduh gratis dari internet, serta untuk memudahkan user dalam menggunakan sistem ini.

\section{Tampilan Depan setelah Login}

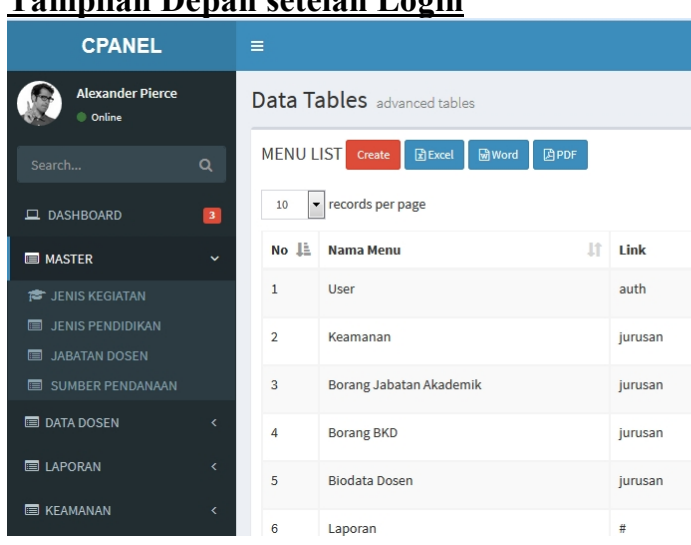

Gambar 6. Tampilan Depan setelah Login

Pada tampilan gambar 4.3 terlihat saat pengguna sudah mengakses sistem. Tampilan ini akan muncul setelah pengguna memasukan user akun yang dimiliki. Yang dibagi menjadi 2 bagian jendela yaitu jendela kanan dan jendela kiri. Pada tampilan jendela kiri ini banyak sekali menu-menu yang ditampilan seperti Master, Data Dosen, Laporan dan Keamanan. Sedangkan pada jendela kanan, saat ini masih menunjukan tabel-tabel pada database nanti akan menunjukan status validasi setiap form yang sudah diinput.
Tampilan Input Identitas Dosen

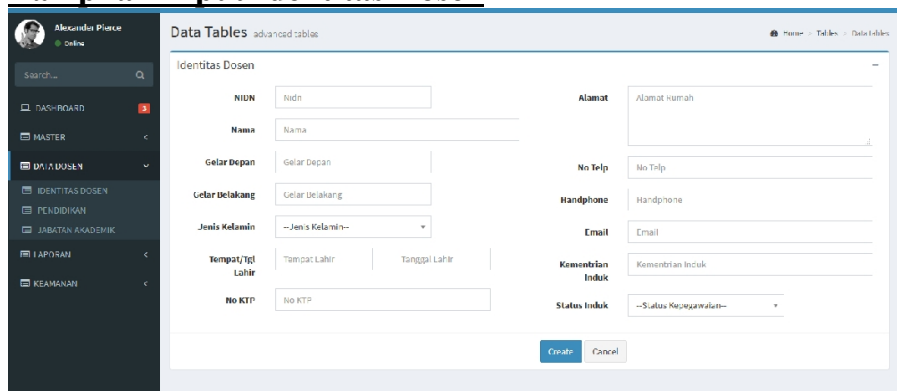

Gambar 7. Tampilan Input Identitas Dosen Pada gambar 7 adalah tampilan form untuk memasukan data dosen yang belum ada. Pada tampilan ini ditampil beberapa isian penting yang menjadi isian utama pada tampilan selanjutnya.

\section{Perancangan Pencetakan}

Pada perancangan pencetakan ini, yang diutamakan adalah berupa dokumen file berbentuk pdf yang dapat dicetak atau disimpan kedalam komputer dosen untuk keperluan pengajuan kenaikan jabatan akademik.

\section{SIMPULAN}

Melihat dari penelitian yang sûdahn dilakuk kan pada sistem yang dibangun næengenai ${ }^{\circ}$ Sistem Informasi Rekam Jejak Dosen, maka dapat diambil kesimpulan sebagai berikut;

Sistem Rekam Jejak Dosen berbasis web, sudah bisa digunakan ${ }^{\text {parent }}$ Secara online ataupun offline didalam jaringan intranet afau WAN untuk niemperticepat suppröses pengisian dan mempermudah monitoping oleh Personalia dan LP2M Undhira

Pembuatan Borang ManMENU kenaikan Jabatan Akademik Dosen bisa lebih mudah dan cepat. Personalia mémiliki pemetaan dâta tể dosen yang berjabatan akademik dan LP2M lebih memotivasi para dosen untuk melakukan Penelitian dan Pengabdian.

\section{DAFTAR PUSTAKA}

1] Rosyada, Dede, Paradigma Pendidikan Demokratis, Sebuah model Pelibatan Masyarakat dalam Penyelenggaraan Pendidikan, Prenadamedia, Jakarta, 2013.

2] Peraturan Pemerintah (PP) No. 37 tahun 2009, Tentang Dosen

3] Peraturan Menteri Pendidikan dan Kebudayaan (Permendikbud) No. 49 tahun 2014, tentang Standar Nasional Pendidikan Tinggi (SNPT). 
4] Undang-Undang No. 14 tahun 2005, tentang Gurud dan Dosen.

5] ${ }^{[1]}$ Dede Rosyada, Paradigma Pendidikan Demokratis, sebuah model pelibatan masyarakat dalam Penyelenggaraan Pendidikan, Prenada Media, Jakarta, 2013, h. 110.

6] ${ }^{[2]}$ Undang-Undang No. 14 tahun 2005 tentang Guru dan Dosen, pasal 1 ayat 2.

7] ${ }^{[3]}$ Undang=Undang No. 14 tahun 2005 tentang Guru dan Dosen pasal 5.

8] ${ }^{[4]}$ Undang=Undang No. 14 tahun 2005 tentang Guru dan Dosen pasal 8 ayat1 poin $b$.

9] ${ }^{[5]}$ Permendikbud No. 49 tahun 2014, pasal 5 ayat, 1,2 dan 3 .

10] ${ }^{[6]}$ Permendikbud No. 49 tahun 2014, pasal 6 ayat 1 poin $\mathrm{a}, \mathrm{b}$ dan $\mathrm{c}$

11] ${ }^{[7]}$ Peraturan Pemerintah (PP) No. 37 tahun 2009, pasal 8 ayat huruf a dan b

12] ${ }^{[8]}$ Permendikbud No. 49 tahun 2014, pasal 27 ayat $1,2,3$ dan 4

13] Dewanto, I. Joko. (2006). Web Desain (Metode Aplikasi dan Implementasi). Yogyakarta: Graha Ilmu.

14] Rachmawati. [Online]. Tersedia: http://elib.unikom.ac.id/files/disk1/52 7/jbptunikompp-gdl-rachmawati26318-5-unikom_r-i.pdf. [29 September 2012, 17.35 WIB].

15] Saleh, Abdul Rahman. (2010). Membangun Perpustakaan Digital: Step by Step. Jakarta: Sagung Seto.

16] Saputro, Hendra W. (2007). Pengertian Website dan Unsurunsurnya.[Online].Tersedia: http://www.balebengong.net/topik/tek nologi/2007/08/01/pengertianwebsite-dan-unsur-unsurnya.html. [29 September 2012, 17.30 WIB].

17] Suyanto, Asep Herman. (2007). Step by Step: Web Design Theory and Practices. Yogyakarta: Andi Offset.

18] . 2012. Definisi dan Pengertian Web Menurut Para Ahli. [Online]. Tersedia:

http://www.sambureki.com/definisi/d efinisi-dan-pengertian-web-menurutpara-ahli.html. [29 September 2012, 17.32 WIB].

19] Kadir Abdul, Dasar Pemrograman Web Dinamis Menggunakan PHP, Andi Offset, Yogyakarta, 2003

20] Sutarman S.Kom, Membangun Aplikasi Web dengan PHP dan MYSQL, Graha Ilmu, Yogyakarta, 2003 